\title{
Yield and nutritional value of biomass sorghum (BRS 716) managed in different row spacing and maturity at harvest in the semiarid region of Brazil
}

\section{Rendimento e valor nutritivo do sorgo biomassa (BRS 716) manejado em diferentes espaçamentos entre linhas de plantio e idades de corte em uma região semiárida do Brasil}

Ícaro Daniel Alves dos Santos Souza ${ }^{1 *}$; Vicente Ribeiro Rocha Júnior²; Flávio Pinto Monção ${ }^{3 *}$; Rafael Augusto da Costa Parrella ${ }^{4}$; Matheus Wilson Silva Cordeiro $^{1}$; Cinara da Cunha Siqueira Carvalho2; João Paulo Sampaio Rigueira2; Ignacio Aspiazú2; Fredson Vieira e Silva²; Nelson de Abreu Delvaux Júnior ${ }^{2}$

\section{Highlights}

Biomass sorghum presents potential for forage production in the semiarid region.

The best maturity at harvest of biomass sorghum BRS 716 is 160 days after planting.

Biomass sorghum showed dry mass yield of $36.61 \mathrm{t} / \mathrm{ha}$ at 160 days (90 cm row spacing).

\section{Abstract}

The objective was to evaluate the structural, yield and nutritional characteristics of biomass sorghum BRS 716 managed in different row planting spacing and harvest age in a semiarid region of Brazil. Three row spacing (45, 70 and $90 \mathrm{~cm}$; plots) and four maturity at harvest (70, 100, 130 and 160 days; subplots) were evaluated following a randomized block design in a $3 \times 4$ split plot arrangement, with eight blocks. The useful area was $3 \times 15 \mathrm{~m}$. Variation in soil fertility in the area was the blocking factor. There was interaction between row spacing and maturity at harvest $(P<0.05)$ on plant height $(P=0.01)$, dry matter yield (DMY; $P<0.01)$ and proportion of senescent material $(P=0.01)$. The DMY observed at the age of 160 days and

1 Students of Animal Science Master's Program, Universidade Estadual de Montes Claros, UNIMONTES, Janaúba, MG, Brazil. E-mail: icaro.ta2007@yahoo.com.br; matheuszoow@gmail.com

2 PhD. Profs., Graduate Program in Animal Science (Master), UNIMONTES, Janaúba, MG, Brazil. E-mail: vicente.rocha@ unimontes.br; cinara.carvalho@unimontes.br; joao.rigueira@unimontes.br; ignacio.aspiazu@unimontes.br; fredson. silva@unimontes.br; nelson.junior@unimontes.br

${ }^{3}$ Prof. and Researcher PNPD/Capes, Graduate Program in Animal Science (Master), UNIMONTES, Janaúba, MG, Brazil. E-mail: moncaomoncao@yahoo.com.br

${ }^{4}$ PhD. Researcher, Empresa Brasileira de Pesquisa Agropecuária, EMBRAPA Milho e Sorgo, Sete Lagoas, MG, Brazil. E-mail: rafael.parrella@embrapa.br

* Author for correspondence

Received: Mar. 03, 2021 - Approved: Apr. 05, 2021 
spacing of $90 \mathrm{~cm}$ was $41.40 \%$ higher than the DMY at the same age and in spacings of 45 and $70 \mathrm{~cm}$ (mean of $21.45 \mathrm{t} / \mathrm{ha})$. As the maturity at harvest increased, there was a reduction in the crude protein content $(\mathrm{P}<$ 0.01), potential degradability $(P<0.01)$ and effective degradability $(P<0.01)$ of dry matter, and the content of non-fiber carbohydrates $(P<0.01)$, total digestible nutrients $(P<0.01)$ and the readily soluble fraction $(P<0.01)$ of the dry matter increased. Considering the yield and nutritional characteristics of biomass sorghum BRS 716 managed in the semiarid region for silage production, the row spacing of $90 \mathrm{~cm}$ and the maturity at harvest of 160 days after planting are recommended.

Key words: Dry matter yield. Height. Ruminal kinetics. Sorghum bicolor.

\section{Resumo}

Objetivou-se avaliar as características estruturais, produtivas e nutricionais do sorgo biomassa BRS 716 manejado em diferentes espaçamentos de plantio e idade de corte em região semiárida do Brasil. Foram avaliados três espaçamentos entre linhas de plantio (45, 70 e $90 \mathrm{~cm}$; parcelas) e quatro de idades de corte (70, 100, 130 e 160 dias; subparcelas) seguindo o delineamento em blocos casualizados em esquema de parcelas subdivididas $3 \times 4$ com oito blocos. A área útil da parcela foi de $3 \times 15 \mathrm{~m}$. A variação da fertilidade do solo da área foi o fator de blocagem. Houve interação do espaçamento de plantio e as idades de corte estudadas $(P<0,05)$ sobre a altura das plantas $(P=0,01)$, produção de matéria seca $(P M S ; P<0,01)$ e proporção de material senescente $(P=0,01)$. A PMS verificada na idade de 160 dias e espaçamento de 90 $\mathrm{cm}$ foi $41,40 \%$ superior a PMS verificada na mesma idade e nos espaçamentos de 45 e $70 \mathrm{~cm}$ (média de $21,45 \mathrm{t} / \mathrm{ha})$. A medida de que aumentou a idade de corte houve redução no teor de proteína bruta $(P<0.01)$, degradabilidade potencial $(P<0.01)$ e degradabilidade efetiva $(P<0.01)$ da matéria seca e aumentou 0 teor de carboidratos não fibrosos $(P<0.01)$, nutrientes digestíveis totais $(P<0.01)$ e a fração prontamente solúvel $(P<0.01)$ da matéria seca. Considerando-se as características produtivas e nutricionais do sorgo biomassa BRS 716 manejado na região semiárida para produção de silagem, recomenda-se o espaçamento entre linhas de plantio de $90 \mathrm{~cm}$ e a idade de corte de 160 dias após o plantio.

Palavras-chave: Altura. Rendimento de matéria seca. Sorghum bicolor. Cinética ruminal.

\section{Introduction}

In many regions of the world, in recent years, Sorghum [Sorghum bicolor (L.) Moench] has become an increasingly important forage crop (Qu, Liu, Dong, Lu, \& Shen, 2014; Amelework, Shimelis, Tongoona, Mark Laing, \& Mengistu, 2015; Rakshit et al., 2016; Perazzo et al., 2017; Mwamahonje \& Maseta, 2018; Worede, Mamo, Assefa, Gebremariam, \& Beze, 2020). This trend is a consequence of the high dry matter yield of sorghum and its ability to adjust to different climatic and soil conditions, which include hot weather, such as in the semiarid region (Perazzo et al., 2017; Mwamahonje \& Maseta, 2018; Borges et al., 2019; Ramos et al., 2021; Rigueira et al., 2021), or relatively cold climates, like Canada, Korea (McCaughey, Therrien, \& Mabon, 1996; Paradhipta et al., 2019).

According to the Food and Agriculture Organization of the United Nations [FAOSTAT] (2020), the main sorghum producing countries are the United States, Nigeria, Sudan, Ethiopia, India, Mexico, and Brazil. In Latin America, 
Brazil, and Argentina are the largest producers of sorghum with 2,272,939 tons and 1,563,445 tons, respectively. In Brazil, the area destined for the cultivation of sorghum in 2020 was 745.3 thousand hectares, of which more than 95\% was destined for animal feed (Companhia Nacional de Abastecimento [CONAB], 2020). In the production of silages for ruminants, forage sorghum has been widely grown in Brazil (Ramos et al., 2021; Rigueira et al., 2021). However, with the uneven rainfall distribution in the semiarid region and other regions of Brazil and the world (Qu et al., 2014), the demand for biomass sorghum for cultivation has grown due to its high dry mass yield, up to 50 t/ha (Castro et al., 2015; May, Souza, Gravina, \& Fernandes, 2016; Almeida et al., 2019) in relation to forage sorghum traditionally grown as Volumax, up to 19 t/ha (Castro et al., 2015). Among biomass sorghum, hybrid BRS 716, launched in 2014 by EMBRAPA Maize and Sorghum, has stood out for its high dry mass yield per unit area, good nutritional value, tolerance to water stress and pests and diseases in Central Brazil (Almeida et al., 2019; Castro et al., 2015; May et al., 2016). In the semiarid region, there are no studies on the harvest management, productivity and nutritional value of BRS 716 biomass sorghum.

According to Monção et al. (2019; 2020), knowing the best age or height for harvesting forage is essential for the balance between mass yield and nutritional value. As the physiological age advances, the plant has its structure, productivity and nutritional value modified, which may alter the digestibility of nutrients. Furthermore, when silage making is intended, processes involved with the fermentation of the ensiled mass and the nutritional value of the silage produced are also influenced (Bernardes et al., 2018; Grant \& Ferraretto, 2018).
In addition to the harvest age, the row planting spacing also affects the productivity and nutritional value of sorghum biomass (May et al., 2016). This is because the spacing between planting rows alters the plant ability to capture light, which can influence the productive, structural and nutritional characteristics of the forage (i.e., stem elongation, thick cell wall, lower concentration of soluble carbohydrates), in addition to interfering with the fermentation process (Borreani, Tabacco, Schmidt, Holmes, \& Muck, 2018; Queiroz et al., 2021). There is no information in the literature on planting spacing and the best age for cutting biomass sorghum BRS 716 regarding this management. According to Monção et al. (2019), in the semiarid region, the intense solar radiation associated with high temperature can change the plant growth pattern, pointing to the need to know the best harvest management of sorghum for silage production.

Based on the above, the objective was to evaluate the structural, productive and nutritional characteristics of biomass sorghum BRS 716 harvested at different ages, and planted in three row spacing in the semiarid region.

\section{Material and Methods}

The procedures for care and handling animals used in the experiment were in accordance with guidelines of the Brazilian College of Animal Experimentation (COBEA) and were approved by the institutional Ethics, Bioethics and Animal Welfare Committee (CEBEA) (case 173/2018).

The experiment was carried out at UNIMONTES Experimental Farm, in the 
municipality of Janaúba (geographical coordinates: $15^{\circ} 52^{\prime} 38^{\prime \prime} \mathrm{S}, 43^{\circ} 20^{\prime} 05^{\prime \prime}$ W), Minas Gerais, from $11 / 13 / 2018$ to $4 / 27 / 2019$. The climate of the region, according to the Köppen (1948) classification, is BSh, with summer rains and well-defined drought periods in winter. The average annual rainfall is $876 \mathrm{~mm}$, with an average annual temperature of $24^{\circ} \mathrm{C}$. The climate is tropical mesothermal, almost megathermal, due to the altitude, sub-humid and semiarid, with irregular rains, causing long periods of drought (Antunes, 1994). The climatic data during the experimental period can be seen in Figure 1.

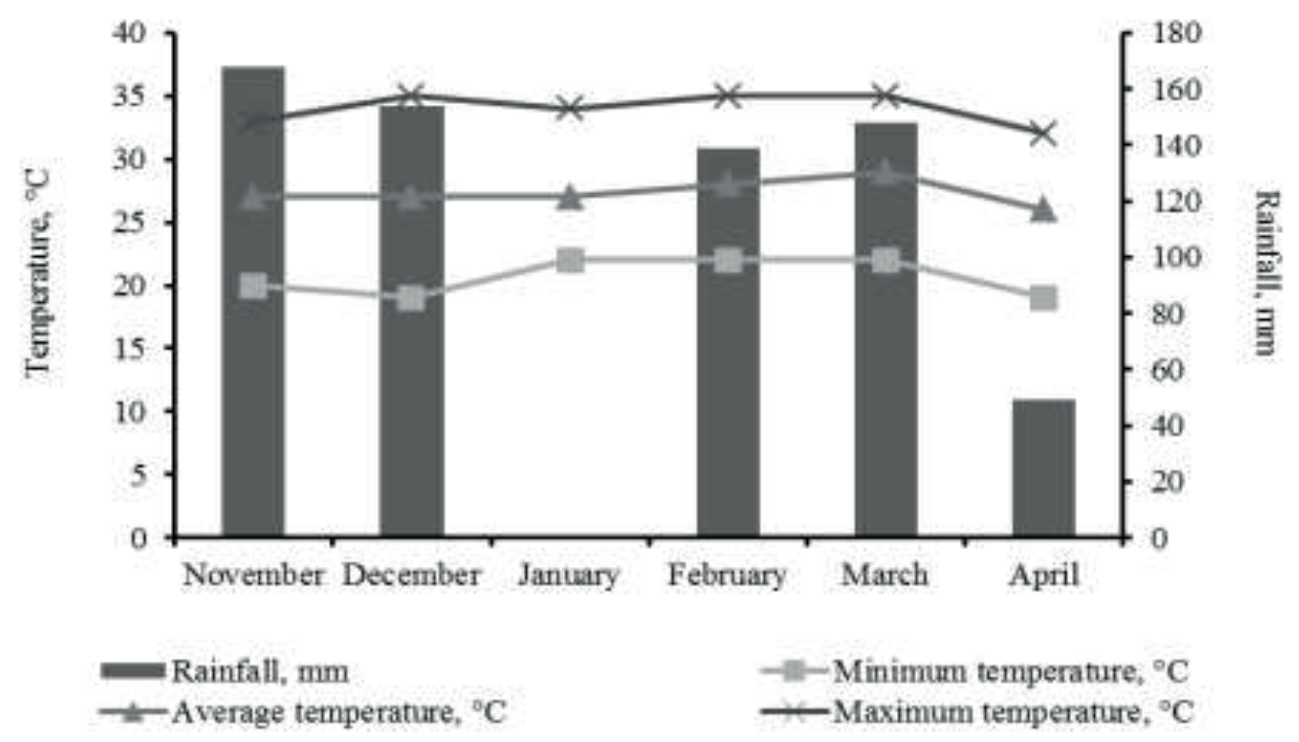

Figure 1. Climatic data during the experimental period.

Source: Instituto Nacional de Metereologia [INMET] (2020).

The experiment was carried out in a flat area $(25 \times 100 \mathrm{~m})$ with biomass sorghum (Sorghum bicolor (L.) Moench) planted in a clayey dystrophic red-yellow latosol with the following chemical characteristics: $\mathrm{pH}$ in $\mathrm{CaCl}_{2}, 6.3 ; \mathrm{P}$ (Mehlich), $21.2 \mathrm{mg} \mathrm{dm}{ }^{-3} ; \mathrm{K}$ (Mehlich), $110 \mathrm{mg} \mathrm{dm}^{-3}$; $\mathrm{Na}$ (Mehlich), $0.3 \mathrm{cmol}_{\text {。 }}$ $\mathrm{dm}^{-3} ; \mathrm{Ca}^{2+}, 3.9 \mathrm{cmol}_{\mathrm{c}} \mathrm{dm}^{-3} ; \mathrm{Mg}^{2+}, 1.1 \mathrm{cmol}^{2}$ $\mathrm{dm}^{-3} ; \mathrm{Al}^{3+}, 0.0 \mathrm{cmolc} \mathrm{dm}^{-3} ; \mathrm{H}+\mathrm{Al}\left(0.5 \mathrm{~mol} \mathrm{~L}^{-1}\right.$ calcium acetate), $1.2 \mathrm{cmol}_{\mathrm{c}} \mathrm{dm}^{-3}$; sum of bases

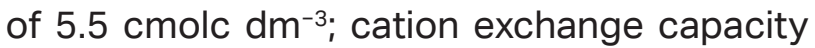

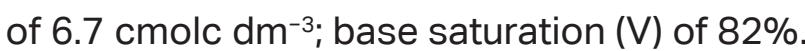
Soil samples were taken for analysis 70 days before planting.
The experiment was conducted using a split-plot completely randomized block design with three row spacings $(45,70$, and $90 \mathrm{~cm}$; 6.3; 9.8 and 12.6 seeds per linear meter) and four ages at harvest $(70,100,130$, and 160 days) and eight blocks, resulting in a total of 96 plots with $5.0 \times 25.0 \mathrm{~m}$ each or a useful area of $3 \times 15 \mathrm{~m}$. Maturities at harvest were chosen due to the high growth of BRS 716 biomass sorghum, adapted from Monção et al. (2019, 2020). Row spacing was defined according to the study of May et al. (2016).

Biomass sorghum was planted in 2018 with seeds donated by Embrapa Maize 
and Sorghum. Before planting, the soil was prepared by plowing and harrowing (twice). During planting, NPK fertilizer (4-14-08) was applied as recommended by the soil analysis for sorghum crop. Supplemental irrigation during the experiment was given according to soil moisture level. Weeds and insects were controlled by manual weeding and insecticides applied by a tractor-mounted sprayer, respectively. At each row spacing and maturity at harvest, forage was manually harvested (25\% total area) and ground using a tractor-mounted harvester model JF-90 Z10 (JF Agricultural Machinery, SP, Brazil) and a New Holland TL 75 tractor (New Holland Agriculture $^{\circledR}$, Paranavaí - PR, Brazil).

Plantheight was measured at five points per plot using a measuring tape, graduated in centimeters, at the time of harvest, measuring from the ground to the insertion of the last leaf blade of the plants. After each pre-established cutting age, a metal frame of $1 \mathrm{~m}^{2}$ was used to manually collect forage samples, $10 \mathrm{~cm}$ above the ground, and estimate the green matter yield (GMY) per area. GMY was estimated based on the number and row planting spacing. Samples were pre-dried in a forced air oven at $55^{\circ} \mathrm{C}$ to constant weight. The dry matter yield was estimated based on the GMY multiplied by the dry matter (DM) content at each maturity at harvest.

Samples were ground in a knife mill with a $1 \mathrm{~mm}$ sieve for analysis of the chemical composition and another part was ground with $2 \mathrm{~mm}$ sieve for in situ incubation. Samples were analyzed for dry matter (INCT-CA G-001/1 and G-003/1), crude protein (INCT-CA $\mathrm{N}-001 / 1)$, ether extract (INCT-CA G-005 / 1), and ash (INCT-CA M-001/1), neutral detergent fiber (INCT-CA F-002/1) and acid detergent fiber (INCT-CA F-003/1), with due corrections for ash (INCT-CA M-002/1) and protein (INCT-CA N-004/1), lignin (INCT-CA F-007/1) and non-fiber carbohydrates, following the recommendations described by Detmann et al. (2012). The content of total digestible nutrients (TDN) was estimated according to National Research Council [NRC] (2001).

For the evaluation of ruminal kinetics of ruminal DM and NDF of sorghum biomass, two crossbred steers, with an average weight of $500 \pm 70 \mathrm{~kg}$ and cannulated in the rumen, were given $4.0 \mathrm{~kg}$ concentrate in two meals, in the morning and in the afternoon, in addition to diets based on biomass sorghum silage for 30 days before incubation. The in situ degradability technique was performed using bags of $7.5 \times 15 \mathrm{~cm}$ non-woven fabric (100 g $\mathrm{m}^{-2}$; Pore size 60 microns) according to Valente et al. (2011); the number of samples was determined from the ratio of $20 \mathrm{mg} \mathrm{DM.cm}{ }^{2}$ of surface area of the bag (Nocek, 1988).

Samples were placed in the ventral sac region of the rumen for $0,3,6,12,24,48,72$, 96,120 , and 144 hours, with the end of the nylon thread tied to the cannula. The zero time bags were not incubated in the rumen, but were washed in running water, similar to the incubated bags. All samples were removed and washed in cold water, aiming to stop rumen fermentation. Subsequently, samples were placed in forced air oven at $55^{\circ} \mathrm{C}$ for 72 hours and then cooled in a desiccator and weighed. The remaining residues in the non-woven bags collected in the rumen were analyzed for the contents of DM and NDF according to the aforementioned methodology. The percentage of degradation was calculated by the proportion of feed remaining in the bags after ruminal incubation. 
Data obtained were fit to a non-linear regression by the Gauss-Newton method, using the SAS 9.0 software (Statistical Analysis System Institute [SAS Institute], 2008), according to the equation proposed by Ørskov \& McDonald (1979): $Y=a+b\left(1-e^{-c t}\right)$, where: $Y=$ accumulated degradation of the analyzed nutritional component, after time $\mathrm{t}$; $a=$ intercept of the degradation curve when $\mathrm{t}=0$, which corresponds to the water-soluble fraction of the analyzed nutritional component; $b=$ potential for degradation of the waterinsoluble fraction of the analyzed nutritional component; $\mathrm{a}+\mathrm{b}=$ potential degradation of the nutritional component analyzed when time is not a limiting factor; $c$ = rate of degradation by fermentation of $b$; $t=$ incubation time. After calculated, the coefficients $a, b$ and $c$ were applied to the equation proposed by Ørskov and Mcdonald (1979): ED $=a+(b \times c / c+k)$, where: $E D=$ effective ruminal degradation of the analyzed nutritional component; $\mathrm{k}=$ rate of passage of the food. The estimated rate of particle passage in the rumen was estimated at $5 \% \mathrm{~h}^{-1}$, as suggested by the Agricultural and Food Research Council [AFRC] (1993). Detail on the fermentation profile and nutritional value of the produced silage can be found in Queiroz et al. (2021).

NDF degradability was estimated using the model proposed by Mertens and Loften (1980): Rt $=B \times e^{-c t}+\mathrm{I}$, where $\mathrm{R}=$ fraction degraded at time $\mathrm{t} ; \mathrm{B}=$ potentially digestible insoluble fraction and $\mathrm{I}=$ indigestible fraction. After adjusting the NDF degradability equation, fractions were standardized as proposed by Waldo, Smith and Cox (1972), using the equations: $\mathrm{Bp}=\mathrm{B} /(\mathrm{B}+\mathrm{I}) \times 100 ; \mathrm{IP}=\mathrm{I} /(\mathrm{B}+$ I) $\times 100$, where: $\mathrm{Bp}=$ standardized potentially digestible fraction (\%); Ip = standardized indigestible fraction (\%); $\mathrm{B}=$ potentially digestible insoluble fraction and $\mathrm{I}=$ indigestible fraction. The effective NDF degradability was calculated according to the model: $E D=$ $\mathrm{Bp} \times \mathrm{c} /(\mathrm{c}+\mathrm{k})$, where $\mathrm{Bp}$ is the standardized potentially digestible fraction (\%).

Data were subjected to analysis of variance using the REG procedures. The UNIVARIATE procedure was used to detect outliers or influential values and to examine the normality of the residuals. The following statistical model was used:

$$
Y i j k=\mu+E i+B j+e i j+I C k+E i x I C j+e i j k
$$

Where: Yijk = observation regarding row planting spacing in sub-plot " $k$ " of the maturity at harvest in plot "i" in block "j"; $\mu=$ constant associated with all observations; $\mathrm{Ei}$ = Effect of row spacing "i", with $i=1,2$ and 3 ; $\mathrm{Bj}=$ Effect of block "j", with $\mathrm{j}=1,2,3,4,5,6,7$ and 8; eij = experimental error associated with the plots that hypothetically have a normal distribution with a mean zero and variance $\delta 2$. ICk = Effect of maturity at harvest "k", with "k" = 1, 2, 3 and 4; Ei $x$ ICj = Effect of the interaction of level "i" of row planting spacing with level " $k$ " of the maturity at harvest; eijk = experimental error associated with all observations ( $Y$ $\mathrm{ijk})$, independent, which by hypothesis has a normal distribution with zero mean and $\delta 2$ variance.

When significant by $\mathrm{F}$ test, the means of row planting spacing and interactions were compared using Tukey's test. The comparisons between the harvest ages were performed by decomposing the sum of squares into orthogonal linear contrasts and quadratic effects, with subsequent adjustments to regression equations. For all statistical procedures, $\alpha=0.05$ was used as the maximum tolerable limit for type I error. 
The ruminal degradability of DM and NDF was conducted in a randomized block design in subdivided plots, with 12 treatments (plots) and 10 incubation times (subplots) and two blocks. The test was conducted twice. Variation in body weight of each animal was the blocking factor. The following statistical model was used:

\section{$Y i j k=\mu+T i+B j+e i j+P k+T i x P i k+e i j k$}

Where: Yijk = observation regarding the time $(P)$ in the sub-parcel $k$ of treatment (T) $\mathrm{i}$ in block j; $\mu=$ constant associated with all observations; $\mathrm{Ti}=$ Effect of treatment "i", with $\mathrm{i}=1,2,3,4,5,6,7,8,9,10,11$ and 12; $\mathrm{Bj}=$ Effect of block $\mathrm{j}$, with $\mathrm{j}=1$ and 2 ; eij = experimental error associated with the plots that, by hypothesis, have a normal distribution with zero mean and $\delta 2$ variance; $P=$ Effect of incubation time $\mathrm{k}$, with $\mathrm{k}=1,2,3,4,5,6,7,8,9$ and 10; TPik = Effect of the interaction of level i of treatment with level $k$ of incubation time; eijk = experimental error associated with all observations that, by hypothesis, have normal distribution with zero mean and $\delta 2$ variance.

When significant by the $F$ test, the treatment means were grouped by Tukey's test. The comparisons between the incubation times were performed by decomposing the sum of squares into orthogonal linear contrasts and quadratic effects, with subsequent adjustments to regression equations. For all statistical procedures, $\alpha=0.05$ was used as the maximum tolerable limit for type I error.

\section{Results and Discussion}

There was a significant interaction between row spacing, and maturity at harvest of biomass sorghum on the plant height ( $P$ $=0.01)$, dry matter yield (DMY; $P<0.01)$ and proportion of senescent material $(P=0.01)$ (Table 1).

For plant height at the ages of 70 and 160 days, there was no difference between the row planting spacing, means of 1.13 and 3.8 meters, respectively. At the age of 100 days, the highest heights were found in the 45 and $90 \mathrm{~cm}$ spacings, while at the age of 130 days, only in the $90 \mathrm{~cm}$ spacing. Analyzing the heights in the spacings of 45,70 and $90 \mathrm{~cm}$, there was an increase of $0.02,0.02$ and 0.03 meters for each day that increased at the harvest age, respectively (Table 2).

For each daily unit increased in the harvest age of the BRS 716 biomass sorghum, there was an increase of $0.069 \%$ in the proportion of stem and a reduction of $-0.098 \%$ and $-0.0015 \%$ in the proportion of leaves and leaf: stem ratio, respectively. These variables were not altered by row spacing.

The BRS 716 biomass sorghum plants managed in the row spacing 45 and $70 \mathrm{~cm}$ had a dry matter (DM) content $4.96 \%$ higher than the value presented in the spacing of 90 $\mathrm{cm}$ (mean of $18.20 \%$; Table 3). Regarding the maturity at harvest, there was a daily increase of $0.13 \%$ and $0.11 \%$ on the content of DM and non-fiber carbohydrates, respectively. For the ash and crude protein variables, there was a linear reduction as the maturity at harvest of the biomass sorghum BRS 716 increased. The row planting spacing affected the crude protein content, with the highest mean in the spacing of $90 \mathrm{~cm}$. 
Table 1

Structural and productive characteristics of the BRS 716 biomass sorghum managed in different row spacing, and maturity at harvest in the semiarid region

\begin{tabular}{|c|c|c|c|c|c|c|c|c|c|c|}
\hline \multirow{2}{*}{ Item } & \multirow{2}{*}{ Spacing } & \multicolumn{4}{|c|}{ Maturity at harvest (days) } & \multirow{2}{*}{ SEM } & \multicolumn{4}{|c|}{ P-value } \\
\hline & & 70 & 100 & 130 & 160 & & IdL & IdQ & Spa & Id x Spa \\
\hline \multirow{3}{*}{$\begin{array}{l}\text { Height, } \\
\text { meters }\end{array}$} & 45 & $1.18 \mathrm{~A}$ & $2.27 \mathrm{~A}$ & $2.63 \mathrm{AB}$ & $3.83 \mathrm{~A}$ & & & & & \\
\hline & 70 & $1.15 \mathrm{~A}$ & $1.77 \mathrm{~B}$ & $2.40 \mathrm{~B}$ & $3.66 \mathrm{~A}$ & 0.08 & $<0.01$ & 0.29 & 0.01 & 0.01 \\
\hline & 90 & $1.07 \mathrm{~A}$ & $2.28 \mathrm{~A}$ & $2.85 \mathrm{~A}$ & $3.91 \mathrm{~A}$ & & & & & \\
\hline \multirow{3}{*}{ DMY, t/ha } & 45 & $9.61 \mathrm{~A}$ & $12.12 \mathrm{~A}$ & $14.68 \mathrm{~B}$ & $20.88 B$ & & & & & \\
\hline & 70 & $6.6 \mathrm{AB}$ & $12.17 \mathrm{~B}$ & $18.13 \mathrm{AB}$ & $22.03 B$ & 1.06 & $<0.01$ & 0.85 & $<0.01$ & $<0.01$ \\
\hline & 90 & $4.9 \mathrm{~B}$ & $11.30 \mathrm{~B}$ & $21.10 \mathrm{~A}$ & $36.61 \mathrm{~A}$ & & & & & \\
\hline \multirow{3}{*}{ Stem, \% } & 45 & 76.32 & 80.51 & 78.02 & 81.50 & & & & & \\
\hline & 70 & 75.10 & 80.55 & 79.55 & 82.11 & 1.15 & $<0.01$ & $<0.01$ & 0.93 & 0.09 \\
\hline & 90 & 71.78 & 81.95 & 80.23 & 82.26 & & & & & \\
\hline \multirow{3}{*}{ Leaf, \% } & 45 & 21.97 & 18.62 & 16.68 & 13.55 & & & & & \\
\hline & 70 & 23.44 & 18.24 & 15.72 & 12.86 & 0.38 & $<0.01$ & $<0.01$ & 0.95 & 0.49 \\
\hline & 90 & 22.64 & 17.23 & 16.32 & 14.02 & & & & & \\
\hline \multirow{3}{*}{$\begin{array}{l}\text { Senescent } \\
\text { Material, \% }\end{array}$} & 45 & $1.70 \mathrm{~B}$ & 0.87 A & $5.29 \mathrm{~A}$ & $4.95 \mathrm{~A}$ & & & & & \\
\hline & 70 & $1.45 \mathrm{~B}$ & $1.21 \mathrm{~A}$ & $4.73 \mathrm{~A}$ & $5.03 \mathrm{~A}$ & 0.89 & $<0.01$ & 0.09 & 0.90 & 0.01 \\
\hline & 90 & $5.59 \mathrm{~A}$ & $0.82 \mathrm{~A}$ & $3.44 \mathrm{~A}$ & $3.71 \mathrm{~A}$ & & & & & \\
\hline \multirow{3}{*}{$\begin{array}{l}\text { Leaf:Stem } \\
\quad \text { ratio }\end{array}$} & 45 & 0.29 & 0.23 & 0.21 & 0.16 & & & & & \\
\hline & 70 & 0.31 & 0.22 & 0.19 & 0.15 & 0.01 & $<0.01$ & $<0.01$ & 0.92 & 0.56 \\
\hline & 90 & 0.32 & 0.21 & 0.20 & 0.17 & & & & & \\
\hline
\end{tabular}

Means followed by different letters in the column (spacing effect) differed by Tukey's test $(P<0.05)$. SEM - standard error of the mean. P - Probability; AgeL = linear e3ffect; AgeQ = quadratic effect; Spa - spacing between planting rows; Id $x$ Spa - interaction between maturity and spacing between planting rows. 


\section{Table 2}

Regression equations of the structural and productive characteristics of the BRS 716 biomass sorghum in different row spacing, and maturity at harvest in the semiarid region

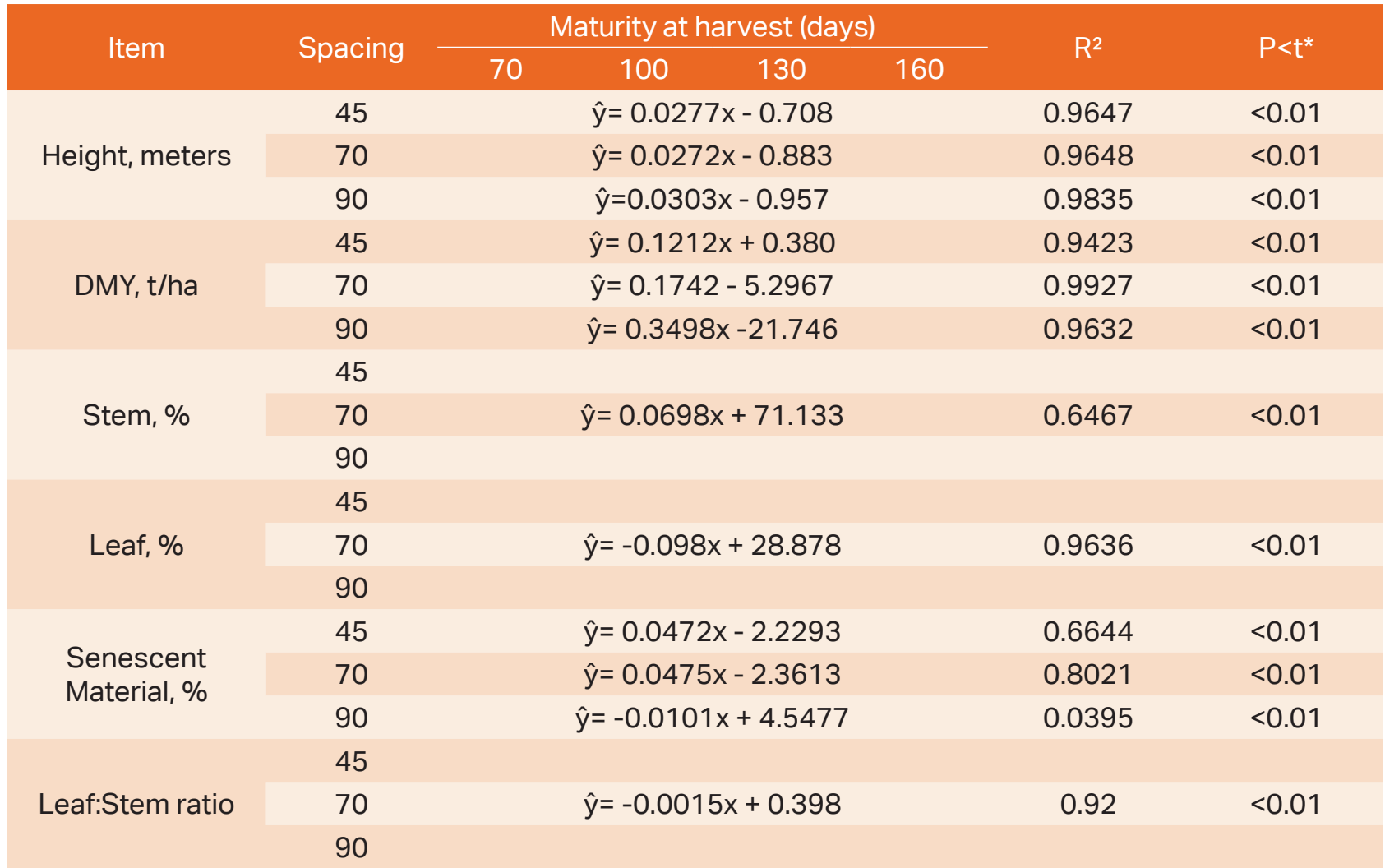

DMY - Dry matter yield; $\mathrm{R}^{2}$ - Coefficient of determination; $\mathrm{P}$ - probability. * Significant by t-test $(\mathrm{P}<0.05)$. 


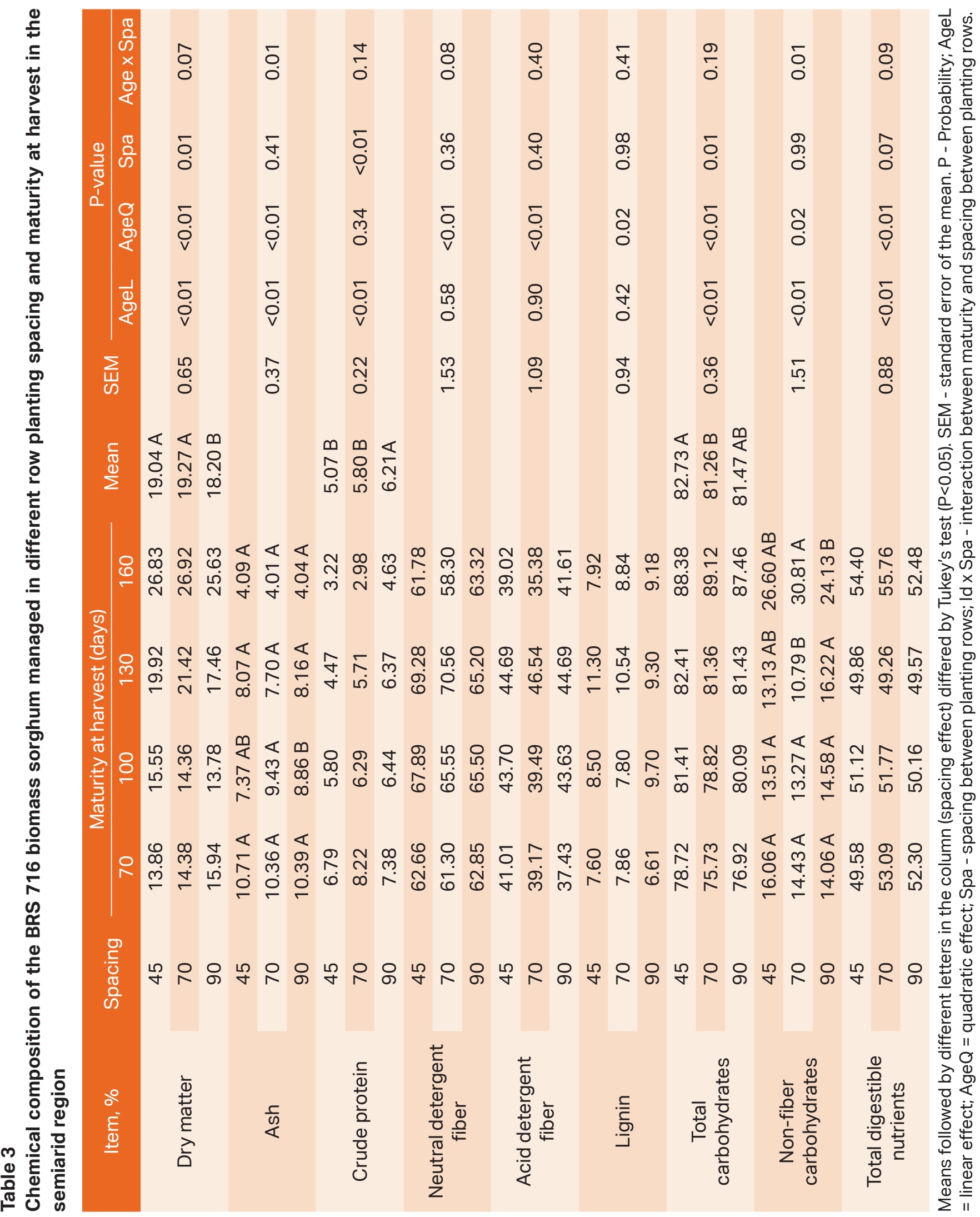


There was no interaction between row planting spacing and maturity of harvest on neutral detergent fiber $(P=0.08)$, acid detergent fiber $(P=0.40)$ and lignin $(P=0.41)$, with means of $64.51 \%, 41.36 \%$ and $8.76 \%$, respectively. The means observed for nonfiber carbohydrates (NFC; $P=0.01$ ) and total digestible nutrients (TDN; $\mathrm{P}=0.09$ ) adjusted to the quadratic regression model as the maturity of harvest increased, with the points being minimum of 104, 108 and 86 days for NFC in the 45,70 and $90 \mathrm{~cm}$ row spacing, respectively (Table 4). For the TDN, the minimum point was at the maturity of harvest of 111.53 days.

There was interaction between row planting spacing and maturity at harvest on fraction $B p(P<0.01)$, degradation rate of the fraction $B p$ " $c$ " ( $P<0.01)$, effective degradability $(P<0.01)$ and undegradable fraction $(P<0.01)$ of the fiber fraction of the biomass sorghum BRS 716 (Table 6).
For fraction $\mathrm{Bp}$, the means adjusted to the quadratic regression model as the maturity at harvest increased. The lowest means for Fraction Bp were verified by the minimum point at the ages of $137.8 ; 132.5$ and 127.22 days in row spacings of 45,70 and $90 \mathrm{~cm}$, respectively (Table 7). When evaluated 70 and 130 days after planting, the highest fraction $\mathrm{Bp}$ was verified in the $70 \mathrm{~cm}$ spacing. When managed at 160 days, the highest mean value was observed at $90 \mathrm{~cm}$ spacing. For effective degradability of the neutral detergent fiber in the maturity at harvest of 70 days, the highest means were found in the row planting spacings of 45 and $90 \mathrm{~cm}$, mean of $41.66 \%$, this being $28.15 \%$ higher than the value observed in row spacing of $70 \mathrm{~cm}$. In the maturity at harvest 100, 130 and 160 days, there was no difference caused by the row planting spacing on the effective degradability, mean of $25.82 \%(k=5 \% / h)$. 
Table 4

Regression equations for the chemical composition variables of the BRS 716 biomass sorghum managed in different row planting spacing and maturity at harvest in the semiarid region

\begin{tabular}{|c|c|c|c|c|c|}
\hline \multirow{2}{*}{ Item } & \multirow{2}{*}{ Spacing } & \multicolumn{2}{|c|}{ Maturity at harvest (days) } & \multirow{2}{*}{$\mathrm{R}^{2}$} & \multirow{2}{*}{$\mathrm{P}<\mathrm{t}^{*}$} \\
\hline & & 100 & 130 & & \\
\hline \multirow{3}{*}{ Dry matter } & 45 & & & 0.88 & $<0.01$ \\
\hline & 70 & $y=0$. & -3.74 & & \\
\hline & 90 & & & & \\
\hline \multirow{3}{*}{ Ash } & 45 & $y=-0$. & 14.73 & 0.84 & $<0.01$ \\
\hline & 70 & $y=-0.6$ & 15.66 & 0.93 & $<0.01$ \\
\hline & 90 & $y=-0$. & 15.28 & 0.9 & $<0.01$ \\
\hline \multirow{3}{*}{ Crude protein } & 45 & & & & \\
\hline & 70 & $y=-0$. & 10.25 & 0.97 & $<0.01$ \\
\hline & 90 & & & & \\
\hline \multirow{3}{*}{$\begin{array}{c}\text { Neutral detergent } \\
\text { fiber }\end{array}$} & 45 & & & & \\
\hline & 70 & $y=-0.0031 x 2$ & $146 x+27.209$ & 0.92 & $<0.01$ \\
\hline & 90 & & & & \\
\hline \multirow{3}{*}{$\begin{array}{l}\text { Acid detergent } \\
\text { fiber }\end{array}$} & 45 & & & & \\
\hline & 70 & $y=-0.0027 x 2$ & $249 x+8.1887$ & 0.83 & $<0.01$ \\
\hline & 90 & & & & \\
\hline \multirow{3}{*}{ Lignin } & 45 & & & & \\
\hline & 70 & $y=-0.0008 \times 2$ & $213 x-3.6068$ & 0.84 & $<0.01$ \\
\hline & 90 & & & & \\
\hline \multirow{3}{*}{$\begin{array}{c}\text { Total } \\
\text { carbohydrates }\end{array}$} & 45 & & & & \\
\hline & 70 & $y=0.1$ & 68.62 & 0.94 & $<0.01$ \\
\hline & 90 & & & & \\
\hline \multirow{3}{*}{$\begin{array}{l}\text { Non-fiber } \\
\text { carbohydrates }\end{array}$} & 45 & $y=0.004 x 2$ & $33 x+55.21$ & 0.96 & $<0.01$ \\
\hline & 70 & $y=0.005 x 2$ & $8 x+65.64$ & 0.91 & $<0.01$ \\
\hline & 90 & $y=0.002 x 2$ & $31 x+27.51$ & 0.99 & $<0.01$ \\
\hline \multirow{2}{*}{$\begin{array}{l}\text { Total digestible } \\
\text { nutrients }\end{array}$} & 45 & & & & \\
\hline & 70 & $y=0.001 x 2$ & $29 x+65.97$ & 0.82 & $<0.01$ \\
\hline
\end{tabular}

$\mathrm{R}^{2}$ - Coefficient of determination; $\mathrm{P}$ - probability. *Significant by t-test $(\mathrm{P}<0.05)$.

There was interaction between row planting spacing and maturity at harvest on fraction $B(P<0.01)$, potential degradability $(P D ; P=0.03$ ), indigestible fraction (iF; $P=0.03$ ) and effective degradability ( $E D ; P=0.01$ ) of the $D M(T a b l e ~ 5)$. For fraction $A$, there was a quadratic behavior as the maturity at harvest increased. The row planting spacing did not modify the components of the ruminal kinetics of DM of the BRS 716 biomass sorghum. 


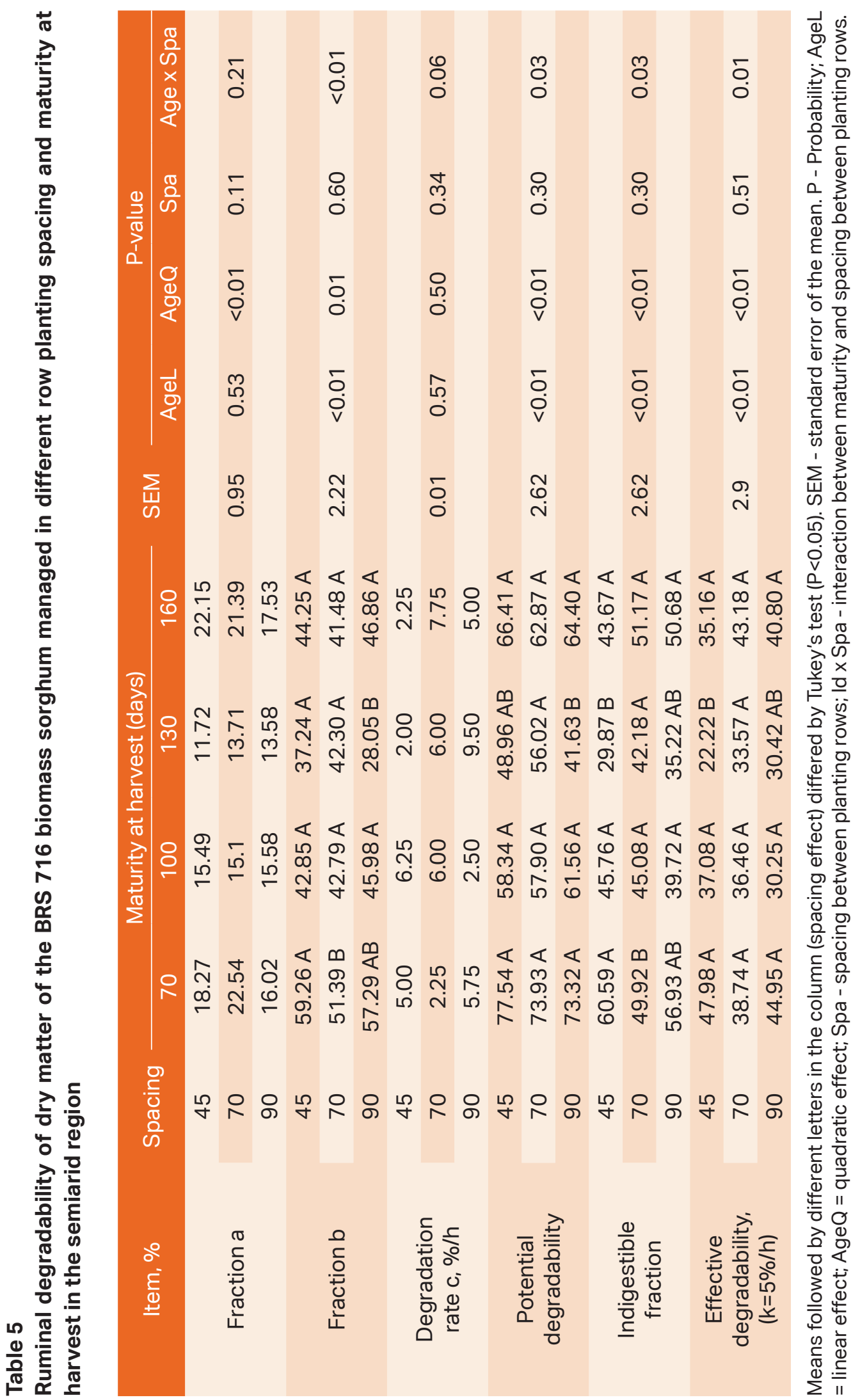




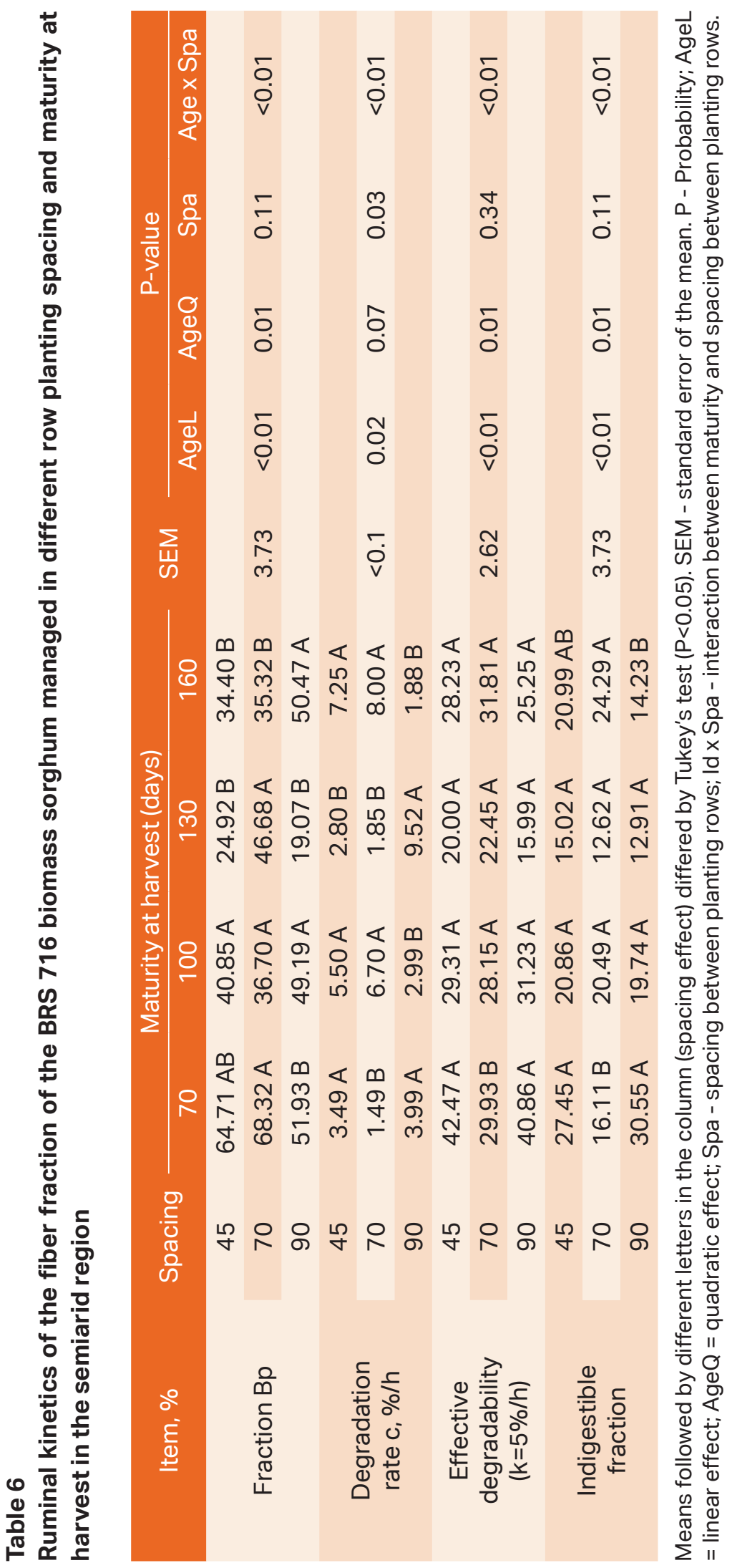


Table 7

Regression equations for ruminal kinetics of dry matter and fiber fraction of the BRS 716 sorghum biomass managed in different row planting spacing and maturity at harvest in the semiarid region

\begin{tabular}{|c|c|c|c|c|}
\hline \multirow{2}{*}{ Item } & \multirow{2}{*}{ Spacing } & Maturity at harvest (days) & \multirow{2}{*}{$\mathrm{R}^{2}$} & \multirow{2}{*}{$\mathrm{P}<\mathrm{t}^{*}$} \\
\hline & & 130 & & \\
\hline \multicolumn{5}{|c|}{ Dry matter } \\
\hline \multirow{3}{*}{ Fraction a } & 45 & & & \\
\hline & 70 & $y=0.004 x 2-0.82 x+58.29$ & 0.80 & $<0.01$ \\
\hline & 90 & & & \\
\hline \multirow{3}{*}{ Fraction b } & 45 & $y=0.006 x 2-1.66 x+144.03$ & 0.99 & $<0.01$ \\
\hline & 70 & $y=-0.10 x+56.07$ & 0.71 & $<0.01$ \\
\hline & 90 & $y=0.008 x 2-2.09 x+160.65$ & 0.79 & $<0.01$ \\
\hline \multirow{3}{*}{$\begin{array}{c}\text { Degradation rate } \\
\text { c, } \% / h\end{array}$} & 45 & & & \\
\hline & 70 & $y=5.02$ & - & ns \\
\hline & 90 & & & \\
\hline \multirow{3}{*}{$\begin{array}{c}\text { Potential } \\
\text { degradability }\end{array}$} & 45 & $y=0.010 x 2-2.48 x+202.39$ & 0.97 & $<0.01$ \\
\hline & 70 & $y=0.006 x 2-1.58 x+153.02$ & 0.99 & $<0.01$ \\
\hline & 90 & $y=0.010 x 2-2.36 x+194.18$ & 0.76 & $<0.01$ \\
\hline \multirow{3}{*}{$\begin{array}{l}\text { Indigestible } \\
\text { fraction }\end{array}$} & 45 & $y=0.008 x 2-2.05 x+166.75$ & 0.90 & 0.01 \\
\hline & 70 & $y=0.004 x 2-0.88 x+93.246$ & 0.91 & $<0.01$ \\
\hline & 90 & $y=0.009 x 2-2.16 x+160.36$ & 0.99 & $<0.01$ \\
\hline \multirow{3}{*}{$\begin{array}{c}\text { Effective } \\
\text { degradability, } \\
(\mathrm{k}=5 \% / \mathrm{h})\end{array}$} & 45 & $y=0.007 x 2-1.70 x+136.18$ & 0.85 & $<0.01$ \\
\hline & 70 & $y=0.003 x 2-0.72 x+73.95$ & 0.83 & $<0.01$ \\
\hline & 90 & $y=0.007 x 2-1.64 x+125.61$ & 0.99 & $<0.01$ \\
\hline \multicolumn{5}{|c|}{ Neutral detergent fiber } \\
\hline \multirow{3}{*}{ Fraction Bp } & 45 & $y=0.009 x 2-2.48 x+194.24$ & 0.98 & $<0.01$ \\
\hline & 70 & $y=0.006 x 2-1.59 x+148.98$ & 0.72 & $<0.01$ \\
\hline & 90 & $y=0.009 x 2-2.29 x+170.64$ & 0.47 & $<0.05$ \\
\hline \multirow{3}{*}{$\begin{array}{c}\text { Degradation rate } \\
\text { c, } \% / h\end{array}$} & 45 & $y=0.001 x 2-0.13 x+9.67$ & 0.42 & $<0.05$ \\
\hline & 70 & $y=0.0003 x 2-0.01 x+2.04$ & 0.33 & $<0.05$ \\
\hline & 90 & $y=-0.002 x 2+0.42 x-17.79$ & 0.32 & $<0.05$ \\
\hline \multirow{3}{*}{$\begin{array}{c}\text { Effective } \\
\text { degradability, } \\
(\mathrm{k}=5 \% / \mathrm{h})\end{array}$} & 45 & $y=0.006 x 2-1.54 x+121.84$ & 0.96 & $<0.01$ \\
\hline & 70 & $y=0.003 x 2-0.71 x+65.55$ & 0.63 & $<0.01$ \\
\hline & 90 & $y=0.005 x 2-1.41 x+115.62$ & 0.86 & $<0.01$ \\
\hline \multirow{3}{*}{$\begin{array}{l}\text { Indigestible } \\
\text { fraction }\end{array}$} & 45 & $y=0.003 x 2-0.88 x+72.96$ & 0.92 & $<0.01$ \\
\hline & 70 & $y=0.002 x 2-0.41 x+36.49$ & 0.35 & $<0.05$ \\
\hline & 90 & $y=0.003 x 2-0.96 x+81.51$ & 0.99 & $<0.01$ \\
\hline
\end{tabular}

$\mathrm{R}^{2}$ - Coefficient of determination; $\mathrm{P}$ - probability. ns - non-significant. ${ }^{*}$ Significant by t-test $(\mathrm{P}<0.05)$. 
Plant height is the result of the relationship between genetic and environmental factors (Shukla, Felderhoff, Saballos, \& Vermerris, 2017). Under appropriate soil and climate conditions, phytomer cells multiply according to their physiological maturity in order to expose leaf blades to light, which changes the height of plants and the proportion of wall components and cell content and is positively related to the accumulation of biomass by the plant (Shukla et al., 2017; Leal et al., 2020). The growth potential of biomass sorghum BRS 716 was favored in the row planting spacing of 90 $\mathrm{cm}$ due to the entry of light inside the forage canopy. Based on the regression equations, the cultivation of sorghum biomass in the spacing of $90 \mathrm{~cm}$ between planting rows resulted in a daily growth of the plant of $3 \mathrm{~cm}$, while in the spacing of 45 and $70 \mathrm{~cm}$, it was $2 \mathrm{~cm}$. This is an important analysis because plants with higher growth reach physiological maturity early, which can be a risk for toppling the canopy if harvested late. Despite the greater growth of sorghum when planted with $90 \mathrm{~cm}$ between rows in relation to the other spacing, at 160 days of cutting age, there was no difference in plant height, with an average of 3.8 meters. The increase in plant height according to the cutting age modified its structure with a higher proportion of stem and senescent material to the detriment of leaves.

Given the positive correlation between height and DMY (Leal et al., 2020), the best DMY results at the highest heights, and harvest age are justified. The DMY verified at the age of 160 days and spacing of $90 \mathrm{~cm}$ was $41.40 \%$ higher than the DMY verified at the same age and in the spacings of 45 and $70 \mathrm{~cm}$ (mean of $21.45 \mathrm{t} / \mathrm{ha}$ ). These results justify the productive potential of biomass sorghum BRS 716 which, even grown in the 45 and $70 \mathrm{~cm}$ spacing, produced more dry matter than the hybrids traditionally grown in Brazil, such as Volumax (DMY of $19 \mathrm{t}$ / ha) and BRS 655 (DMY of $13 \mathrm{t} / \mathrm{ha}$ ) considering 120 days of planting and spacing between planting rows of $70 \mathrm{~cm}$, according to Castro et al. (2015). Regarding planting spacing, May et al. (2016) observed an increase of $33.6 \%$ in the DMY of sorghum biomass when the spacing between planting rows was reduced from 110 $\mathrm{cm}$ to $50 \mathrm{~cm}$. These fluctuations in results may occur due to the plant stand in the area, and in smaller spacing it is possible to increase the number of plants in the area. In this research, regardless of the planting spacing, a density of 140 thousand plants/ha (6.3; 9.8 and 12.6 seeds per linear meter) was expected. As the plant reached physiological maturity, there was a daily increase in DMY of 117.38; 167.39 and $338.02 \mathrm{~kg} / \mathrm{ha}$ in the spacing of 45,70 and $90 \mathrm{~cm}$, respectively. The higher DMY observed in the present study justify the possibility of using biomass sorghum as forage material in semiarid regions. As the short rainy season is distributed irregularly, in these regions, forage productivity by area should be optimized.

As the plant reaches physiological maturity, changes in fiber components occur at the expense of cellular content, rich in nutrients with greater digestibility (Monção et al., 2019). These changes were verified in this research with an increase in the dry matter and fiber content as a function of the harvest age. Kung, Shaver, Grant and Schmidt (2018) recommended a dry matter content of $25 \%$ for forage grasses to be ensiled. In this study, from 160 days of age, it was possible to verify that dry matter content, which is important to avoid losses by effluents. McDonald, Henderson and Heron (1991) stated that, when there is an adequate amount of soluble 
carbohydrates, $20 \%$ DM are sufficient to ensure good fermentation. In this way, it is possible to ensile the sorghum biomass with 130 days of harvest age, but to avoid losses of DM it is important to use moisture sequestering additives or use the pre-wilting technique to increase the dry matter content of the silage mass (Muck et al., 2018). The use of additives such as bran (above 88\% DM) during ensiling grasses with high moisture can increase production costs. However, it improves the fermentation and the nutritional value of the silage, in addition to anticipating the sprouting of sorghum and preventing tipping of the canopy that can happen at heights above 2.5 meters. When harvested at 160 days of age, sorghum biomass flourished due to sensitivity to the photoperiod. According to Parrella, Rodrigues, Tardin, Damasceno and Schaffert (2010), the flowering of sorghum biomass only occurs after the inductive photoperiod, which is 12 hours and 20 minutes.

Despite the presence of the sorghum panicle at the age of 160 days, there was a dilution effect on the ash, protein and fiber contents. NDF and ADF showed a quadratic regression behavior, despite having increased linearly up to 115.25 days, and 115.72, respectively, as the maximum point. Due to the greater amount of non-fiber carbohydrates present in sorghum grains harvested after 160 days, there was an increase in the content of total carbohydrates and total digestible nutrients of the plant. However, the means of these variables showed a quadratic regression behavior. This behavior was also verified in the readily soluble fraction of the dry matter (fraction "a"). This occurred because the presence of grains increased the content of soluble carbohydrates and other soluble components of the plant harvested at 160 days. This is important because the soluble fractions of the feed contribute to the production of short-chain and branched fatty acids in the rumen, being the main source of energy for ruminants. The fraction "b" characterized as a water-insoluble but potentially degradable fraction was also modified with the presence of the panicle, increasing the potential degradability of the dry matter of the whole plant harvested at 160 days in relation to the ages of 100 and 130 days. The fraction " $b$ " is mostly related to the extent of degradation of the fiber fraction of the forage. The anticipation of the biomass sorghum harvest for 130 days is favorable for regrowth, however, the ruminal kinetics of DM, and NDF allows inferring in obtaining mass with less potential for degradation. Despite presenting higher DMY at the harvest age of 160 days and in the spacing between planting rows of $90 \mathrm{~cm}$, Queiroz et al. (2021) reported that the best fermentation profile and nutritional value of the biomass sorghum silage BRS 716 was found at the row planting spacing of $70 \mathrm{~cm}$, and harvest age of 160 days.

Biomass sorghum BRS 716 is forage with a high potential for mass production with good nutritional value, being an important option for ruminant farming in semiarid regions. Based on the nutritional value of this forage observed in this study, it is worth mentioning that the use of this forage can be indicated for several categories of animals. However, depending on the production level, there is a need to adjust the protein and energy levels of the diet. In F1 $1 / 2$ Holstein $\times 1 / 2$ Zebu cows in the middle third of lactation, Ramos et al. (2021) found that milk yield was not modified when forage sorghum silage (Volumax) was replaced with biomass sorghum silage (BRS 716) harvested at 160 days after planting, and $70 \mathrm{~cm}$ of row planting spacing. The forage: concentrate ratio of the diet was 75:25. 


\section{Conclusion}

Considering the yield and nutritional characteristics of the biomass sorghum BRS 716 managed in the semiarid region for silage production, the row planting spacing of $90 \mathrm{~cm}$, and the maturity at harvest of 160 days after planting are recommended.

\section{Acknowledgments}

The authors would like to thank the Fundação de Amparo à Pesquisa do Estado de Minas Gerais (FAPEMIG), Universidade Estadual de Montes Claros (Unimontes), Conselho Nacional de Desenvolvimento Científico e Tecnológico (CNPq), Instituto Nacional de Ciência e Tecnologia (INCT - Ciência Animal), and Embrapa Maize and Sorghum, for their assistance with scholarships/research. This study was financed in part by the Coordenação de Aperfeiçoamento de Pessoal de Nível Superior - Brasil (CAPES) - Finance Code 001. The authors would like to thank the undergraduate students for their contribution towards the accomplishment of the research.

\section{References}

Agricultural and Food Research Council (1993). Energy and protein requirements of ruminants. Walligford: CAB International.

Almeida, L. G. F., Parrella, R. A. da C., Simeone, M. L. F., Ribeiro, P. C. de O., Santos, A S. dos, Costa, A. S. V.,... Schaffert, R. E. (2019). Composition and growth of sorghum biomass genotypes for ethanol production. Biomass and Bioenergy, 122(1), 343-348. doi: 10.1016/j.biombioe. 2019.01 .030
Amelework, B., Shimelis, H., Tongoona, P., Mark Laing, M., \& Mengistu, F. (2015). Genetic variation in lowland sorghum (Sorghum bicolor (L.) Moench) landraces assessed by simple sequence repeats. Plant Genetic Resources, 13(2), 131-141. doi: $10.1017 / S 1479262114000744$

Antunes, F. Z. (1994). Caracterização climática. Informe Agropecuário, 17(139), 15-19.

Bernardes, T. F., Daniel, J. L. P., Adesogan, A. T., McAllister, T. A., Drouin, P., Nussio, L. G.,... Cai, Y., (2018). Silage review: unique challenges of silages made in hot and cold regions. Journal of Dairy Science, 101(5), 4001-4019. doi: 10.3168/jds.2017-13703

Borges, L. D. A., Rocha, V. R., Jr., Monção, F. P., Soares, C., Silva, F. V., Rigueira, J. P. S.,... Rabelo, W. O. (2019). Nutritional and productive parameters of Holstein/Zebu cows fed diets containing cactus pear. Asian-Australasian Journal of Animal Sciences, 32(9), 1373-1380. doi: 10.5713/ ajas. 18.0584

Borreani, G., Tabacco, E., Schmidt, R. J., Holmes, B. J., \& Muck, R. E., (2018). Silage review: factors affecting dry matter and quality losses in silages. Journal of Dairy Science, 101(5), 3952-3979. doi: 10.3168/ jds.2017-13909

Castro, F. M. R., Bruzi, A. T., Nunes, J. A. R., Parrella, R. A. C., Lombardi, G. M. R., Albuquerque, C. J. B., \& Lopes, M. (2015). Agronomic and energetic potential of biomass sorghum genotypes. American Journal of Plant Sciences, 6(6), 18621873. doi: 10.4236/ajps.2015.611187

Companhia Nacional de Abastecimento (2020). Acompanhamento da safra brasileira, grãos. Recuperado de https:// www.conab.gov.brl 
Detmann, E., Souza, M. A., Valadares, S. C., F., Queiroz, A. C., Berchielli, T. T., Saliba, E. O. S.,... Azevedo, J. A. G., (2012). Methods for food analysis. Visconde do Rio Branco: Suprema.

Food and Agriculture Organization of the United Nations (2020). Countries by commodity- Sorghum. Retrieved from http://www.fao.org/faostat/en/\#rankings/ countries_by_commodity

Grant, R. J., \& Ferraretto, L. F. (2018). Silage review:silage feeding management:Silage characteristics and dairy cow feeding behavior. Journal of Dairy Science, 101(5), 4111-4121. doi: 10.3168/jds.2017-13729

Instituto Nacional de Metereologia (2020). Estações e dados/dados metereológicos. Recuperado de http://www.inmet.gov. br/portal/index.php?r=estacoes/esta coesAutomaticas

Köppen, W. (1948). Climatologia: Con un estudio de los climas de la tierra. México: Fondo de Cultura Econômica.

Kung, L., Jr., Shaver, R. D., Grant, R. J., \& Schmidt, R. J., (2018). Silage review: interpretation of chemical, microbial, and organoleptic components of silages. Journal of Dairy Science, 101(1), 4020-4033. doi: 10.3168/ jds.2017-13909.

Leal, D. B., Monção, F. P., Rocha, V. R., Jr., Carvalho, C. C. S., Alencar, A. M. S., Moura, M. M. A.,... Rigueira, J. P. S. (2020). Correlações entre as características produtivas e nutricionais do capim-BRS capiaçu manejado na região semiárida. Brazilian Journal of Development, 6(4), 18951-18960. doi: 10.34117/bjdv6n4 $-168$
May, A., Souza, V. F., Gravina, G. A., \& Fernandes, P. G., (2016). Plant population and row spacing on biomass sorghum yield performance. Ciência Rural, 46(3), 434439. doi: 10.1590/0103-8478cr201411 33.

McCaughey, W. P., Therrien, M. C., \& Mabon, R., (1996). Forage sorghum in southern Manitoba. Canadian Journal of Plant Science, 76(1), 123-125. doi: 10.4141/ cjps96-019.

McDonald, P., Henderson, A. R., \& Heron, S. J. E. (1991). The biochemistry of silage (2nd ed.). Marlow: Chalcombe Publications.

Mertens, D. R., \& Loften, J. R. (1980). The effects of starch on forage fiber digestion kinetics in vitro. Journal of Dairy Science, 63(9), 1437-1446. doi: 10.3168/jds.S00 22-0302(80)83101-8

Monção, F. P., Costa, M. A. M. S., Rigueira, J. P. S., Moura, M. M. A., Rocha, V. R., Jr., Mesquita, V. G.,... Chamone, J. M. A. (2019). Yield and nutritional value of BRS capiaçu grass at different regrowth ages. Semina: Ciências Agrárias, 41(5), 745-755. doi: 10. 5433/1679-0359.2019v40n5p2045

Monção, F. P., Costa, M. A. M. S., Rigueira, J. P. S., Sales, E. C. J., Leal, D. B., Silva, M. F. P.,... Rocha, V. R., Jr. (2020). Productivity and nutritional value of BRS capiaçu grass (Pennisetum purpureum) managed at four regrowth ages in a semiarid region. Tropical Animal Health and Production, 52(1), 235-241. doi: 10.1007/s11250019-02012-y

Muck, R. E., Nadeau, M. G., McAllister, T. A., Contreras-Govea, F. E., Santos, M. C., \& Kung, L., Jr. (2018). Silage review: recent advances and future uses of silage 
additives. Journal of Dairy Science, 101(5), 3980-4000. doi: 10.3168/jds.2017-13839

Mwamahonje, A., \& Maseta, Z. (2018). Evaluation of yield performance of sorghum (Sorghum bicolor L. Moench) varieties in Central Tanzania. International Journal of Agronomy and Agricultural Research, 13(1), 8-14.

National Research Council (2001). Nutrient requirements of dairy cattle (7nd rev. ed.). Washington, DC: National Academies Press.

Nocek, J. E. (1988). In situ and other methods to estimate ruminal protein and energy digestibility: a review. Journal of Dairy Science, 71(8), 2051-2069. doi: 10.3168/ jds.S0022-0302(88)79781-7

Ørskov, E. R., \& Mcdonald, I. (1979). The estimation of degradability in the rumen form incubation measurement weighted according to rate of passage. Journal of Agricultural Science, 92(2), 499-508. doi: $10.1017 / S 0021859600063048$

Paradhipta, D. H. V., Joo, Y. H., Lee, H. J., Lee, S. S., Kim, D. H., Kim, J. D., \& Kim, S. C. (2019). Effects of inoculant application on fermentation quality and rumen digestibility of high moisture sorghumsudan grass silage. Journal of Applied Animal Research, 47(1), 486-491. doi: 10. 1080/09712119.2019.1670667

Parrella, R. A. C., Rodrigues, J. A. S., Tardin, F. D., Damasceno, C. M. B., \& Schaffert, R. E. (2010). Desenvolvimento de híbridos de sorgo sensíveis ao fotoperíodo visando alta produtividade de biomassa. (Boletim de Pesquisa e Desenvolvimento, n. 28). Sete Lagoas, MG: EMBRAPA Milho e Sorgo.
Perazzo, A. F., Carvalho, G. G. P., Santos, E. M., Bezerra, H. F. C., Silva, T. C., Pereira, G. A.,... Rodrigues, J. A. S. (2017). Agronomic evaluation of sorghum hybrids for silage production cultivated in semiarid conditions. Frontiers in Plant Science, 8(1), 1-8. doi: 10.3389/fpls.2017.01088

Qu, H., Liu, X. B., Dong, C. F., Lu, X. Y., \& Shen, Y. $X$. (2014). Field performance and nutritive value of sweet sorghum in eastern China. Field Crops Research, 157(1), 84-88. doi: 10.1016/j.fcr.2013.12.010.

Queiroz, F. E., Rocha, V. R., Jr., Monção, F. P., Rigueira, J. P. S., Parrella, R. A. C., Rufino, L. D. A.,... Cordeiro, M. W. S. (2021). Effect of row spacing and maturity at harvest on the fermentative profile, aerobic stability, and nutritional characteristics of biomass sorghum (BRS 716) silage in the semiarid region of Brazil. Revista Brasileira de Zootecnia, 50(1), e20200254. doi: 10.37 496/rbz5020200254

Rakshit, S., Ganapathy, K. N., Gomashe, S. S., Dhandapani, A., Swapna, M., \& Mehtre, S. P. (2016). Analysis of Indian post-rainy sorghum multi-location trial data reveals complexity of genotype $\times$ environment interaction. Journal of Agricultural Science, 1(1), 1-16. doi: 10.1017/S002 1859616000137

Ramos, J. C. P., Rocha, V. R., Jr., Monção, F. P., Parrela, R. A. C., Caxito, A. M., Cordeiro, M. W. S.,... Pires, D.A.A. (2021). Effect of replacing forage sorghum silage with biomass sorghum silage in diets for F1 Holstein $\times$ Zebu lactating cows. Tropical Animal Health and Production, 53(1), 1-12. doi: 10.10 07/s11250-020-02503-3 
Rigueira, J. P. S., Jesus, N. G., Rocha, V. R., Jr., Monção, F. P., Costa, N. M., David, G. S. S.,... Carvalho, C. C. S. (2021). Effects of different banana crop wastes on nutrient intake and digestibility, microbial protein synthesis, feeding behavior, and animal performance of $3 / 4$ Holstein $\times$ Zebu heifers in a semiarid rangeland. Tropical Animal Health and Production, 53(1), 1-13. doi: 10.1007/s11250-021-02660-z

Statistical Analysis System Institute (2008). SAS/Stat 9.2 Users guide. Cary, NC, USA: SAS Institute, Inc.

Shukla, S., Felderhoff, T. J., Saballos, A., \& Vermerris, W. (2017). The relationship between plant height and sugar accumulation in the stems of sweet sorghum (Sorghum bicolor (L.) Moench). Field Crops Research, 203(1), 181-191. doi: 10.1016/j.fcr.2016.12.004
Valente, T. N. P., Detmann, E., Queiroz, A. C., Valadares, S. C., Fo., Gomes, D. I ., \& Filgueiras, J. F. (2011). Evaluation of rumen degradation profiles of forages using bags made from different textiles. Revista Brasileira de Zootecnia, 40(11), 2565-2573. doi: 10.1590/S1516-35982 011001100039

Waldo, D. R., Smith, L. W., \& Cox, L. E. (1972). Model of cellulose disappearance from the rumen. Journal of Dairy Science, 55(1), 125-129. doi: 10.3168/jds.S00220302(72)85442-0

Worede, F., Mamo, M., Assefa, S., Gebremariam, T., \& Beze, Y. (2020). Yield stability and adaptability of lowland sorghum (Sorghum bicolor (L.) Moench) in moisture-deficit areas of Northeast Ethiopia. Cogent Food \& Agriculture, 6(1), 1736865. doi: 10.1080/23311932.2020.1736865 
